\title{
TOWARDS TREASURY 4.0/THE EVOLVING ROLE OF CORPORATE TREASURY MANAGEMENT FOR 2020
}

\author{
Petr Polak* \\ Francois Masquelier** \\ Grzegorz Michalski***
}

Received: 19. 5. 2018

Professional paper

Accepted: 12. 12. 2018

UDC 005.915:004

DOI https://doi.org/10.30924/mjcmi/2018.23.2.189

\begin{abstract}
This paper highlights the importance of treasury management in a corporate world. Treasury management is a dynamic phenomenon, and treasurers need to update treasury activities accordingly. This paper aims to provide a future roadmap for treasury management. In the near future, the most important aspects of treasury management will be new financial regulations, developments in information technology, and global approaches toward whole business operations. In this regard, the concept of business intelligence has become a need of the highest
\end{abstract}

\section{INTRODUCTION}

Corporate finance and treasury management have achieved an intersection that becomes salient when planning the role of a treasurer in the dynamic career of treasury management for the near future. The credit crunch crisis from 2007 to 2009 extended developments in the job descriptions of treasurers over the past nine years as a result, and the treasurer's job has changed significantly. Due to a turbulent environment, new factors have risen that will importance for every CFO. Treasury management needs to put aside the traditional practice of setting financial targets for one year and think of medium-term treasury planning as a source of significant motivation. Treasury management is a dynamic profession that evolves continuously, seeks maximum effectiveness, and aims for the highest productivity and simplification of all treasury activities.

Keywords: treasury 4.0, treasury evolution, digitization, globalization, business intelligence.

persuade changes in corporate treasuries. As an example of this, it is essential to mention modern financial procedures and protocols, advancements in information technology across the board, and the internationalization of businesses' operations. Finance and treasury experts characterize this as a second evolution phase of the treasury. Such factors are the agents of change in the treasurer's profession and demand adaptability to a treasury environment, which is already unstable and in a paradigm shift. It is said that anticipating means managing, so it is treasurers'

\footnotetext{
* Petr Polak, Associate Professor of Finance, UBDSBE, University of Brunei Darussalam, Gadong, Brunei Darussalam; visiting at Shaanxi Normal University, Xi’an, China, e-mail: petr.polak.68@gmail.com

** Francois Masquelier, Head of Treasury and Enterprise Risk Management, RTL Group, Luxembourg; Chairman of ATEL, Luxembourg; Vice-Chairman of the EACT (European Association of Corporate Treasurers)

*** Grzegorz Michalski, Associate Professor of Finance, Wroclaw University of Economics, Wroclaw, Poland
} 
responsibility to come up with treasury narratives and invoke innovative situations about treasuries' roles in the future, which will enable a company to understand what narrative and situation works best in the second phase of treasury evolution.

\section{LITERATURE REVIEW}

Roszkowska and Prorokowski (2017) investigate "the contemporary role of banks' treasuries and show how the treasury function is being transformed across the banking sector," discussing the current and future challenges faced by corporate treasuries. Polak, Robertson, and Lind (2011) analyze how the modern corporate treasurers function in multinational companies (MNCs) focusing on the transformation of the treasurer role in response to current business challenges. According to these authors, the most significant trigger creating change in the role of the corporate treasurer is the global financial crisis of 2007 to 2011. This moved the focus from earnings to cash and liquidity and marked the era of the easy availability of cash for corporate financing. In this paper, the authors further describe the end of a credit expansion fostered by the financial deregulation of the 1980s and point to the constraints in hedging exposures to foreign exchanges and interest rates. In addition, management of liquidity and proper measurement of risks has been disrupted, while embedded risks (such as vendor and customer contracts) have also emerged as critical issues. This has led to the transformation of the treasury, from performing the functions of cash management, funding, and hedge accounting toward a strategic function focused on securing liquidity and managing the risk profiles of corporations.

Ramiah, Zhao, Moosa, and Graham (2016) analyze the behavior of corporate treasurers in charge of decision-making as related to cash, inventory, accounts receivable, accounts payable, and risk management during the financial crisis. They used a survey to determine if managers were prone to different forms of heuristic-driven biases (including aversion to losses, high confidence levels, anchoring, and self-serving biases). They were able to identify some aspects of behavioral biases. Some of these biases were described as leading to "suboptimal decisions in certain areas of working capital management (WCM)", but also could represent "desirable attributes in other aspects of WCM." Moosa and Ramiah (2017) analyze behavioral biases and their implications for decision-making in finance. The authors claim that the narcissism of corporate treasurers is demonstrated as a prevalent behavior in the finance industry and that it can be identified as one of the triggers of the global financial crisis.

Chauhan and Banerjee (2018) investigate the existence of optimal or target levels of working capital for India-based manufacturing firms and whether the firms intentionally follow the targets or not. They use the cash conversion cycle to measure working capital and employ the dynamic panel models to analyze the behavior of following the targets.

\section{EVOLUTION OF THE CORPORATE TREASURY FUNCTION, FROM TREASURY 1.0 TOWARD TREASURY 4.0.}

\subsection{Development of the treasurer's role}

To succeed in a rapidly changing environment, corporate treasurers need to develop new skills and competences. They need to undertake new tasks and challenge major 

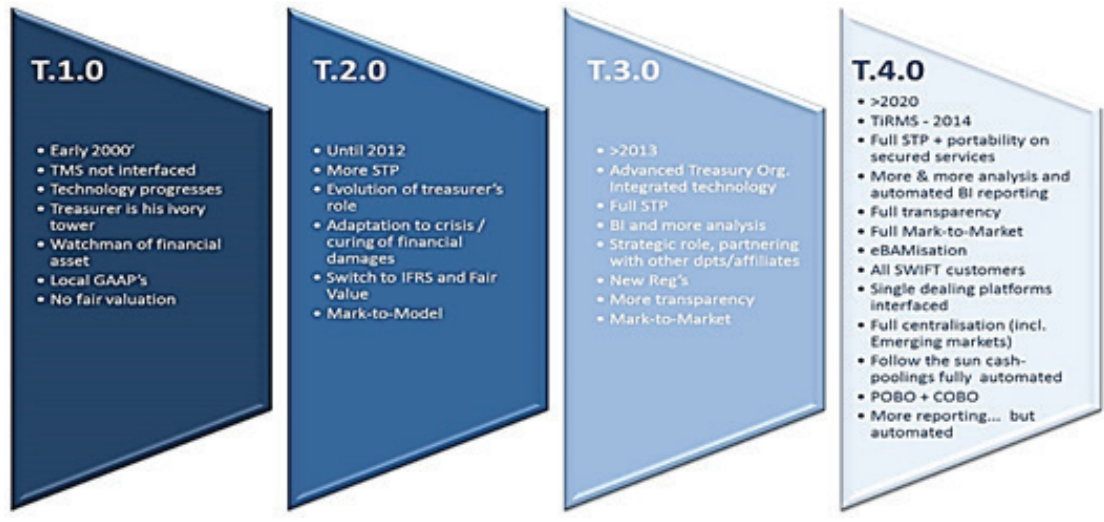

Source: Authors

technological changes as they face a shifting and oppressive business environment. It is an ongoing challenge, and it entails the prospect of several years of hard work. Figure 1 illustrates the major changes that are expected. Corporate treasurers have already moved from Treasury 2.0 (T.2.0) to T.3.0. The move to T.4.0 (or Version 4.0) will be an objective for 2020. It involves endeavors for organic modification within the pursuit of greater profitability and efficiency.

Today's world has become a complex place. The treasury profession is now dealing with three main risk categories: (1) economic and regulatory environment-related risk, (2) operational risk and (3) political, security, and security of information risks. The geographical scope of the treasurer's profession has expanded globally to include emerging countries and regions that are complicated to handle and have many specific provisions in the area of, for example, withholding tax, restrictive and protectionist policies, repatriation of profits prohibitions, and foreign exchange controls. Information technology is a great help for treasurers on one hand, but it is also dangerous if it is not kept secure. The treasury community expects fraud to be one of the major problems it will face in the following years.

The watchwords for Treasury 4.0 are clear: to encrypt messages, protect data against cyber-attacks, obtain ISO and other required certifications, send messages by eBAM to improve bank connectivity, remove all the paper documentation from the process, adopt standardized XML formats such as 3Skey to secure systems access, and provide $100 \%$ automation. The strategic and operational tasks are becoming rather complex, with all corporations in general and also individual companies being vulnerable.

The banking relationship in T.4.0 will also rationalize itself thanks to the Single Euro Payment Area development and new technological solutions. In a corporate treasury environment, it is quite common to have cash pooling accounts and certain virtual accounts, thus cutting down operating costs. Rationalizing and shortening financial cycles and the processing sequence, having better cash and working capital 
requirement forecasts, electronic invoicing, and having simpler procedures and other approvals are the main objectives for a corporation's survival nowadays. Corporate treasurers are taking more and more part in implementing corporate group strategies. Financial investors expect greater efficiency and profitability for their investments in companies and also are aware of how the top management controls their companies.

\subsection{Toward fully automated and fully centralized treasuries}

Corporate treasury management is moving into its second phase of functional evolution. During this stage, the main drivers should be related to new regulatory developments, technological drivers and changes, as well as the general economic environment, in which the focus will be placed on transparency. The corporate treasury is expected to work on an open-book basis with a total fair value. To challenge such changes (which are coming together with the expected major changes in IFRS), corporate treasurers need to improve their skills and capabilities (both soft and hard skills), lock in to get a handle on new errands and capacities, add new technologies to improve corporate productivity and efficiency, and keep adapting to ever more restrictive legislation and regulatory environments. Companies need to have efficient and centralized organizational structures to achieve this. Greater efficiency is a keyword everywhere, and the treasury functions cannot avoid it either. Luckily, new technology can be viewed as a quickening agent rather than a brake, regardless of whether each new framework includes adjustments and devours a lot of time and vitality at the beginning

Figures 1 and 2 provide a broader view of the evolution expected in the coming years. Productivity, flexibility, analytical skills, and regulatory compliance are the keywords for T.4.0 functions. At the same

Figure 2. Drivers of the 'Treasury 4.0' function evolution

\begin{tabular}{|l|}
\hline Required skills ( $\bullet$ ) \\
\hline \hline - Flexibility/adaptability \\
- Multi-knowledges \\
- Legal background \\
- Customers/affiliates-centric \\
- IT expert in-house \\
- Capability to train/to educate and \\
to retain young talents \\
- Reporting \& analytic skills \\
- Mobility in case of treasury HQ \\
relocation \\
- Deep tax knowledge \\
- Multi-languages/culture \\
- Communicationsskills reinforced \\
- More creativity and capacity to \\
innovate \\
- Negotiation skills strengthening \\
- IFRS expertise \\
- Capacity to move out of comfort \\
zone
\end{tabular}

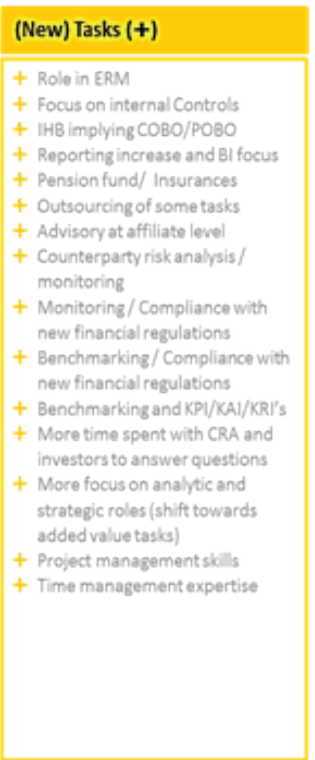

IT Systems/Tech (e)
(e. From TMS forwards TIRMS
One-dealing platform for all
financial instruments/assets
All solutions on SaaS mode
Treasurers-to-Treasurers
solutions
payment means
Cyber threats as a focus
sortability on other devices (e.8.
smartphones and tablets)
Full digitalisation of signature /
More integrated mutli-functions
It solutions
Increase recourse to pre-paid
cards
More video conferences and less
business trips

\begin{tabular}{|c|}
\hline onte \\
\hline $\begin{array}{l}\text { I Rapidly changing economic } \\
\text { environment } \\
\text { ! More financial regulations to } \\
\text { master } \\
\text { ! New accounting standards } \\
\text { (towards full Fair Value) } \\
\text { I More recourse to capital market } \\
\text { fundingv. less bank financing } \\
\text { I Increasing costs of compliance } \\
\text { I Basel III impacts on Corporates } \\
\text { ! Focus on financial risks } \\
\text { I More stock-exchange listing } \\
\text { (several listings across the world) } \\
\text { ! Complete giobalisation of } \\
\text { activities including new emerging } \\
\text { countries } \\
\text { I Quest for more transparency } \\
\text { I More uniformed AR/AP landscape } \\
\text { ! Bank as supplier in Finance Supply } \\
\text { Chain and trade solutions (shorter } \\
\text { cycles) } \\
\text { ! All processes ISOed / } \\
\text { Normalisation of standards } \\
\text { applied / Soc } 1 \text { type } 2 \text { / COSO2. } \\
\text { ! Permanent quest for cost-cutting } \\
\text { (e.g. less and less bank accounts of } \\
\text { virtual accounts under main one's) }\end{array}$ \\
\hline
\end{tabular}


time, we can expect a greater role of the internal controls in the company that will lead to full automation and then straightthrough processing (STP) for systems integration. Corporate treasury management is being plunged into the approach of a single system with multiple functions that are interoperable and modular, instead of the previously used multisystem approach. And as a final stage, use of an in-house bank to cover all the treasury and finance activities and serve as a center of expertise, control, and point of transit to execute fully automated flows of securely encrypted and fast financial transactions is expected. As the ultimate level of this, we can also expect the introduction of "Payment on Behalf of" (POBO) and "Collection on Behalf of" (COBO). In T.4.0, companies are expected to handle their cash following the sunfrom the Asia-Pacific in the East through Europe and the Middle East up to the Americas in the West, considering only tax efficiency. Companies will have fewer bank accounts under the Single Euro Payment Area and with virtual sub-accounts. At the end of the day, corporate treasury management is moving to eBAM, e-billing, eprocurement, future e-services, common and enterprise-wide XML standards, and "follow-the-sun" cash management/cash pooling solutions. There will never again be any idle cash lying around. In overseeing financial risk, treasurers will look ideal in all cases and consider each perspective to fuse the impacts of connection decorrelation to oversee chance ideally. Management of financial risk will never again be a disconnected pocket approach, but a worldwide and coordinated methodology, with devices to help with basic leadership and business intelligence reports that will address the issues of the boards of directors and audit committees. Especially because of greater expected involvement in corporations' strategic analyzing and decision-making, the corporate treasurers will again find their place at the top of the organizational structure and also a good reasoning for their existence. The gradual change from producing financial reports, although sometimes sophisticated, to a phase of evaluation, planning, and supporting decision-making seems to be another significant challenge for T.4.0. Treasurers are expected to provide strategic recommendations to help CFOs make final decisions. Corporate treasuries are increasingly important suppliers to the CFOs, and there is high stress placed on the quality of their work. The treasurer function is moving up the job pyramid toward more strategic and advisory tasks with higher added value. Operational matters will become relatively less important (we can expect many fewer repetitive, low-value-added tasks in T.4.0) or even be outsourced.

Figure 3. Evolution of the task pyramid

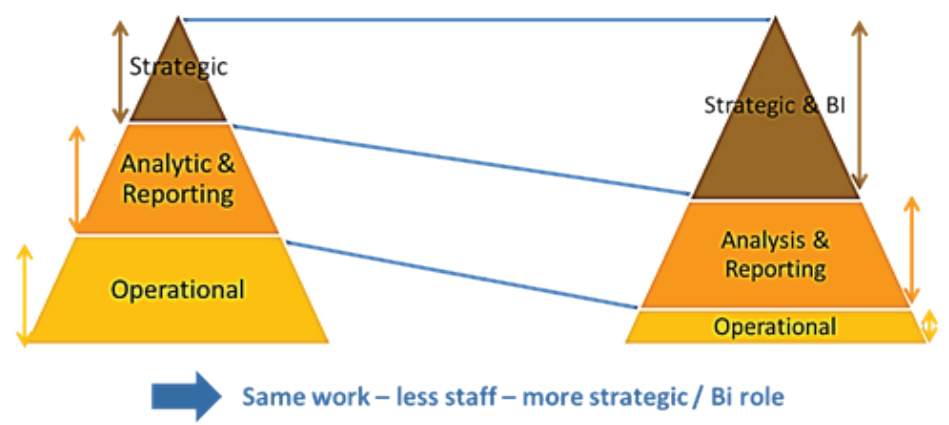

Source: Authors 


\section{4. "TRADITIONAL" TREASURY TASKS 10 YEARS AFTER THE GLOBAL FINANCIAL CRISIS}

Since the 2007-2009 global financial crisis, corporate treasuries have had to adjust to a number of regulatory changes and a volatile macroeconomics environment and learn to respond to changing working practices, especially automation and digitization. However, it appears that cash and liquidity are still the top priority for corporate treasurers, even in 2018 , to ensure access to funding, with the treasury often focused on cost-effectiveness.

\subsection{Cash and liquidity management}

One of the current challenges for treasury management is embracing diverse trading models, currencies, and payment and collection methods and practices without losing control over liquidity and risk. Liquidity these days is moving faster than during any period before. Developments such as instant payment systems are seeing clearing cycles, reaching the point of being almost immediate. At the same time, the development of mobile payments is causing seven-day-perweek, 24-hour-per-day cash flows at much higher frequencies. At the same time, various SWIFT initiatives mean that such acceleration also pertains to cross-border and global flows as well. The tempo of liquidity is also increasing and is likely to continue doing so. Higher-speed liquidity opens the way to intraday cash and liquidity forecasting. It helps foster the effective use of internal sources of liquidity throughout the day.

The role of the corporate treasurer has become increasingly complex, so corporate treasuries are aiming for automation and more efficient software with the goal of gaining clear visibility of all bank accounts, enhanced liquidity, reductions in the number of days in accounts receivables, increased collection rates, and sped up overall financial profitability.

\subsection{Treasury centralization}

Centralization of the treasury management processes is a common first step to achieve a greater efficiency of treasury operations. Most MNCs have already completed the third (or final) stage of centralization of treasury management, or they are near completion. However, even if a company has centralized its organizational structure and treasury management, it still needs to standardize and simplify both the internal and external processes, and all of this must be done before going to automation and digitization of the treasury.

\subsection{Banking relationships}

The nature of bank relationships has been changing over the years as well. In charge of this change, some initiatives are originating from the banking sector itself, for example technological developments and industry consolidation. Others are the result of economic changes, such as globalization, competitive pressures, and the recent global financial crisis.

Regarding globalization, banks have had to adjust to, for example, the Single Euro Payment Area (SEPA), expand their operations internationally, extend their global business networks, be in compliance with local legislation and regulations, and be able to support the operation of MNCs and optimize cash and liquidity management globally, in both developed and emerging markets. This, in turn, requires a detailed understanding of the corporate customer's business model and operating environment.

\subsection{Financial risk management}

Most financial managers and/or corporate treasurers would find their primary role 
to be in financial risk management within their corporations rather than in other parts of treasury management. Financial risk management is always a responsibility of the treasury (or finance) department in a corporation. The process of risk management in a company includes identifying different types of financial risk, measuring them, defining financial risk management policies and standards, reporting on progress, and, of course, periodically re-assessing policies. In line with recent experiences are the treasurers' continuing concerns with managing credit risk to businesses and banks, market risk, operational risk, and liquidity risk.

Market risk consists of individual risks, managed traditionally by the treasury, such as interest rate risks, foreign exchange risks, security prices risks, and commodity prices risks. While some treasurers are fairly specialized in managing individual risk areas, such as credit risk and different types of operational risk, it is becoming necessary for treasurers to be able to manage a full spectrum of market risks themselves. While the economic environment is still turbulent, it is very important to manage company exposures, especially in the foreign exchange and commodity markets, while adequate attention should be also paid to the interest rates, since they are at historically low levels in the developed markets.

\section{FACING NEW EMERGING CHALLENGES IN CORPORATE TREASURY MANAGEMENT}

The role of the treasurer has changed profoundly and expanded during recent years due to different factors, especially regulatory, fiscal, and technical developments. The corporate treasurer has become a very important part of the strategic decision process in companies. As the keyword nowadays is profitability, the treasury profession aims for efficiency and competitiveness.

\subsection{From standardization to digitization of treasury management as a part of Treasury 4.0}

The digitization of the economy and its consequent impact on all companies and industries is a fact, so the traditional treasurer's world is under pressure to go out of its comfort zone and follow these challenges. As with other finance functions, corporations, and jobs, treasuries have been confronting difficulties, changes and advancements over the last 10 years, since the end of the credit crunch crisis. Actually, the corporate treasury management function has evolved over many years, but more significantly over the last decade.

The treasury function is a relatively young function, first known from the end of the 1940s, and it has evolved rapidly since that time, especially since the last financial crisis. The financial crisis was a kind of impetus for further principle changes in treasury management that have been achieved through the digitization of the market. Digitization already influenced treasury management recently in conjunction with new standards (Single Euro Payment Agreement) and means (e.g. bank payment obligations), which combine all the advantages, such as rapid processing, of the outgoing and incoming payments with mitigation of risks in cash collection, improvement of bilateral trading relations between trading partners, and solving of difficulties with payment terms and conditions. Further technology changes, such as transactions platforms, cross-bank bidding platforms, 
and virtual subsidiary accounts, have been developed and will further impact treasury management.

Digitization is changing the way the world does business, as it covers multiple technologies that can be used to optimize existing processes and services or to support the creation of entirely new services and ecosystems. Some of these technologies have widespread business applications, such as blockchain or distributed ledger technology (DLT), while others, such as mobile money support, are for more specific activities like managing payments. These will likewise be a test for MNCs endeavoring to encourage digitization, especially as the exploratory idea of the digital economy does not generally adjust well inside a rigid structure. Treasury management digitization requires standardized and clearly defined business processes, including the necessary data, interfaces, end products, and responsibilities.

\subsection{Going global}

Globalization continues to be a driving force in the world economy; it creates new opportunities for companies, from small businesses to MNCs, to develop, grow, and expand. Treasury management plays an important role in any company's globalization efforts, especially in the areas of cash management, banking relationships, managing foreign exchange risk, and mergers and acquisitions overseas. Treasury departments must address all the developments in managing liquidity internationally across regions and markets and in different currencies and companies, especially the need to keep up with regional cash and liquidity nuances in the emerging markets, as well as regulatory issues.

With the development of globalization and the opening of new markets, it is increasingly complex to ensure compliance with relevant regulations, especially with different regulatory frameworks across a range of regions and countries.

A related challenge is the difficulty of centralizing and repatriating cash held internationally. This is relatively easy in developed markets, but in many emerging countries and regions, the obstacles are greater due to currency and capital controls, including domestic and cross-border cash pooling. Basel III is also creating cash management challenges as tools such as notional cash pooling are likely to no longer be offered by banks to corporations, prompting immediate action in regional and global cash and liquidity management. For example, in the European single market, there has been developed a simpler method of transferring money between banking systems. SEPA has improved the efficiency of cross-border payments and allows cross-border payments between different EU and EFTA member countries as cheaply and easily as domestic payments, effectively harmonizing and streamlining the transfer of liquidity around Europe. A further benefit is the reduction of bank fees for European businesses for payments and collections around the area.

\section{CONCLUSION}

The role of the corporate treasurer has changed profoundly and expanded during recent years due to different factors, especially regulatory, fiscal, and technical developments. The corporate treasurer has become a very important part of strategic decision processes in companies. As the keyword nowadays is profitability, the treasury profession aims for efficiency and competitiveness.

Corporate treasuries have to set aside the traditional practice of planning for a 
full year. Several professionals set annual targets for themselves and strive to achieve them. There is a need to forgo traditional paths, plan for the medium term, and commit to it. It should be a strong motivation for all treasurers. A new, dynamic era of treasury management invokes significant challenges, but it also presents an opportunity for treasurers to adapt accordingly and

\section{References}

1. Chauhan, G. S., Banerjee, P. (2018). Financial constraints and optimal working capital - evidence from an emerging market. International Journal of Managerial Finance, 14(1), 37-53.

2. Moosa, I. A., Ramiah, V. (2017). The financial consequences of behavioural biases: An analysis of bias in corporate finance and financial planning. London: Palgrave (pp. 1-174)

3. Polak, P., Robertson, D.C., Lind, M. (2011). The new role of the corporate make finance departments efficient, competitive, and dynamic. Still, despite all the new challenges and progress in treasury management achieved during the last decade, it looks like cash and liquidity are still the top priority for corporate treasurers, even in 2018 , to ensure access to funding, with the treasury often focused on cost-effectiveness.

treasurer: Emerging trends in response to the financial crisis. International Research Journal of Finance and Economics, 78, 48-69.

4. Ramiah, V., Zhao, Y., Moosa, I., Graham, M. (2016). A behavioural finance approach to working capital management. European Journal of Finance, 22(8-9), 662-687.

5. Roszkowska, P., Prorokowski, L. (2017). The changing role of a bank's treasury. Asia-Pacific Journal of Financial Studies, 46(6), 797-823.

\section{PREMA RIZNICI 4.0 - RAZVOJ ULOGU KORPORACIJSKOG RIZNIČKOG MENADŽMENTA ZA 2020. GODINU}

\section{Sažetak}

U ovom se radu naglašava značaj rizničkog menadžmenta za korporacije. Riznički menadžment je dinamički fenomen, a rizničari trebaju na odgovarajući način osvježavati svoj pristup rizničkim aktivnostima. U radu se pokušava pružiti prikaz budućeg razvoja rizničkog menadžmenta. U bliskoj budućnosti, najznačajniji će aspekti rizničkog menadžmenta biti nova financijska regulacija, razvoj informatičke tehnologije te globalni pristup promatranju poslovnih operacija. U ovom smislu, „poslovna inteligencija“ postaje potrebom najviše razine za svakog glavnog menadžera/icu financija. Riznički se menadžment mora odreći tradicionalnih praksi postavljanja jednogodišnjih financijskih ciljeva i usmjeriti se na srednjoročno rizničko planiranje. Riznički je menadžment dinamička profesija, koja se stalno razvija, traži maksimalnu efektivnost te teži najvišoj razini produktivnosti i pojednostavnjenja svih rizničkih aktivnosti. 